Quest Journals

Journal of Research in Business and Management

Volume 4 Issue 9 (2016) pp: 08-14

ISSN (Online ) : 2347-3002

www.questjournals.org

Research Paper

\title{
The Effect of Competence, Motivation and Organizational Culture on Employee Performance: the Mediating Role of Organizational Commitment
}

\author{
Agustina Rantesalu ${ }^{1}$, Abdul Rahman Mus ${ }^{2}$, Mapparenta $^{3}$, Zaenal Arifin ${ }^{4}$
}

Received; 24 October 2016 Accepted; 05 November 2016; (C) The author(s) 2016. Published with open access at www.questjournals.org

\begin{abstract}
The purpose of this study to analyze the effect of competence, motivation and organizational culture on organizational commitment and employee performance. The research was conducted at the Institute of Education and Training of South Sulawesi province with a population of 513 employees and based on Slovin formulation; sample set as many as 224 employees. Research hypothesis was tested by using Structural Equation Models (Analysis of Moment Structures, AMOS version 18). The study found that the competence and organizational culture has a positive and significant effect on organizational commitment. Work motivation has a negative and insignificant effect on organizational commitment. Competence, organizational culture and organizational commitment have a positive and significant effect on employee performance. Work motivation has a negative and insignificant effect on employee performance. Organizational commitment as a mediating variable in explaining the effect of work motivation on employees performance, whereas in, explains the effect of competency and organizational culture on performance, organizational commitment is not proven
\end{abstract}

Keywords - Competence, motivation, organizational culture, commitment, employee performance

\section{BACKGROUND TO RESEARCH}

The demands on the arrangement of good governance and challenges in the implementation of public service management that is transparent and responsibilities momentum for the direction of government bureaucracy Indonesia as well as in the education and training in South Sulawesi to realize the paradigm good government with provides education and training to qualified personnel, for it has become a necessity for those involved in the implementation of education and training to have the competence and high motivation and culture organizations are better able to increase organizational commitment and employee performance is no higher than the standard of state civil apparatus (ASN) performance at the working unit in accordance with the objects of work and work behavior of employees and the Indonesian Government Regulation No. 46 - 2011 on performance appraisal.

The reality shows that the performance assessment is based on the aspects of quantity, quality, cost and time (The Indonesian Government Regulation No. 46, 2011). Performance is the achievement of the work which exceeded the target set (Phillips, 2007: 65). The low of employees performance resulting from the low organizational commitment, that the employee does not comply with all the rules laid down in the organization, ignoring the commitment to always be part of the organization and does not give serious attention to sustain the success already achieved by the organization. Smith \& Meyer (2009: 56) states that everyone in the organization must be committed to advance, comply with the rules, become part of the organization and strive to maintain the organization's success has been achieved. The core of this organizational commitment includes four elements, namely affective, normative, and continuance, prospective as demands for realizing the objectives of the organization. The findings of previous researchers provide evidence that organizational commitment has a positive and significant effect on individual performance (Bani \& AlHawary, 2009; Kanfer et al., 2010; Rosa, 2011; Sujana, 2012).

Under the regulation, the employee performance evaluation agency Training South Sulawesi province refers to the performance appraisal assessed in four aspects: quantity, quality, time and cost. Conditions that occur in the Education and Training of South Sulawesi province, showed that, the conditions and the ability of employees to perform in accordance with the standards of achievement assessment of performance by targets of state civil apparatus (ASN) is not in accordance with the reality of the expected review of aspects of quantity, quality and time and costs used in the completion of the work. For it is shown as follows: 
Table 1. Employee performance based on performance standards

\begin{tabular}{|c|c|c|c|c|}
\hline \multirow{2}{*}{ Year } & \multicolumn{4}{|c|}{ Actual Performance (\%) } \\
\cline { 2 - 5 } & Quantity & Quality & Time & Cost \\
\hline 2011 & 89.54 & 85.63 & 72.25 & 70.89 \\
\hline 2012 & 84.66 & 82.39 & 70.63 & 67.92 \\
\hline 2013 & 81.28 & 78.18 & 69.32 & 65.74 \\
\hline 2014 & 78.62 & 75.46 & 64.28 & 60.58 \\
\hline 2015 & 76.66 & 72.11 & 61.84 & 59.97 \\
\hline
\end{tabular}

Source: Institute for education and training of South Sulawesi Province (2016)

The table shows the percentage of performance that does not achieve performance targets Based on performance standards of state civil apparatus (ASN), in which the realization of the expected target 90-100\%. It is seen that the performance is based on aspects of the quantity of work within a period of five years has decreased, in 2011 amounted to $89.54 \%$ and then in 2015 decreased by $76.66 \%$, that the implementation of education and training held reduced. Employee performance based on the quality of work, in 2011 reached $85.63 \%$ and then in 2015 decreased to $72.11 \%$. The quality of education is low. Furthermore, based on aspects of the use of working time employee in 2011 amounted to $72.25 \%$, then in 2015 continued to decline until it reaches $61.84 \%$. Performance is based on the utilization of cost-effectiveness, in 2011 reached $70.89 \%$ and in 2015 decreased to $59.97 \%$. The low of employees performance due to low and have not been as good or organizational commitment, competence, motivation and organizational culture.

The low of the employees competence is the antecedent of the lack of organizational commitment and employee performance. The condition is caused by the level of education, skills, experience, work attitude in the mastery and expertise based on professionalism owned employee is at a low level. That is based on knowledge, employees still dominated by an employee with a bachelor's degree level so that the employee is deemed not to have enough knowledge to do the job. Skills deemed necessary to be improved through a training program so that they have the ability to work high. The experience of employees in work is still limited to daily activities, work attitude which is not oriented to innovation and the proficiency level of the work has not been professional in his field, so these factors into consideration for enhanced competencies. Competent human resources in the wake of the substance of the knowledge, skill, experience, work attitude and skill mastery. High competent used to increase organizational commitment and individual performance (Donald, 2007: 1). The empirical evidence shows that the competence of positive and significant effect on commitment and performance (Bani \& AlHawary, 2009; Kanfer et al., 2010; Rosa, 2011; Sujana, 2012).

Employees in work require passion, encouragement and support to always survive, to grow or thrive while the other part meeting the needs of employees is relatively low for the low motivation of the employment. ERG Theory of Clayton Alderfer explains that each individual needs to be motivated to meet the needs of existence, relationship and growth is usually called the needs of the ERG. Elements ERG covers the demands of subsistence, physical needs, family needs, needs social, employment needs and the needs of the productive and creative. The findings of previous researchers provide evidence that the work motivation has a positive and significant effect on organizational commitment and individual performance (Moon, 2000; Burton et al., 2002; Guritno \& Waridin, 2005; Suharto \& Budi Cahyono, 2005; Hakim, 2006; Devi, 2009; Gunastri, 2009; Haryono, 2009).

Organizational culture which is not implemented properly became the cause of organizational commitment and employee performance, that employee has not been able to understand well the organizational culture of the workplace, this is evidenced by the lack of integrity of personnel in work and low employee responsibilities in completing the work, as well as the level of discipline and low compliance so that the execution of the job is not as expected. The value of philosophy explained that the philosophy of the organization's founder advanced and modern philosophy is always based on five values: integrity, identity, responsibility, and discipline and results orientation. Empirical evidence suggests that organizational culture has a positive and significant effect on organizational commitment and individual performance (Moon, 2000; Fey \& Denison, 2003; Abdul Rashid et al., 2003; Jandeska \& Kraimer, 2005; Cuong \& Swierczek, 2008; Manetje \& Martins, 2009; Zain et al., 2009; Ojo, 2009).

\subsection{Employee competence}

\section{LITERATURE AND HYPOTHESES DEVELOPMENT}

Placement of employees in positions according to their competence is also one of the deciding factors in improving job satisfaction. Competence is the basic characteristics of a person that affect thinking and action, 
to generalize to all situations faced and survived long enough in humans (Ruky, 2006). Competence in relation to the performance can be classified into two groups: the threshold competencies are the minimum criteria that must be met office holders in order to work effectively and differentiating competencies are the criteria that distinguish people who achieve superior performance and individuals with individuals who produce an average performance (Ruky, 2006). Competence regarding the authority of each individual to perform a task or making decisions appropriate to their role in the organization that are relevant to the expertise, knowledge, and capabilities. The competency of individual employees should be able to support the implementation of the strategy of the organization and be able to support any changes made to management. In other words, the competence of the individual can support team-based work systems (Rivai, 2008: 289).

Competencies of human resources constructed of the substance of the knowledge, skill, experience, work attitude and skill. High competent used to increase organizational commitment and individual performance (Thierauf, 2008). The empirical evidence shows that the competence has a positive and significant effect on organizational commitment and employee performance (Bani \& AlHawary, 2009; Kanfer et al., 2010; Rosa, 2011; Sujana, 2012). Thus, the proposed hypothesis of the study as follows:

$\mathrm{H}_{1 \mathrm{a}}$ Competence has a positive and significant effect on organizational commitment

$\mathrm{H}_{1 \mathrm{~b}}$ Competence has a positive and significant effect on employee performance

\subsection{Work motivation}

Motivation of the self-employees can be derived from the need for money, awards, power, and recognition. Motivation from outside can come from family, co-workers and superiors. In outline the motivation to work is divided into two parts, namely a positive motivation and negative motivation. Positive motivation is the process of influencing people by providing the possibility of getting a gift while negative motivation is the process of influencing a person through the power of fear such as loss recognition, money or position (Heidjrachman \& Husnan, 2002). Other views classifying work motivation into intrinsic motivation, namely the driving of work sourced from within the workers in the form of awareness of the meaning of the work performed. Extrinsic motivation is driving labor sourced from outside the workers in the form of a condition that requires carrying out the work to the maximum (Nawawi, 2000).

ERG Theory of Clayton Alderfer explains that each individual needs to be motivated to meet the needs of existence, relationship and growth is usually called ERG needs. ERG element covers the demands of subsistence, physical needs, family needs, and social needs, the needs of the job and the needs of the productive and creative. The findings of previous researchers provide evidence that the work motivation has a positive and significant effect on organizational commitment and individual performance (Moon, 2000; Burton et al., 2002; Guritno \& Waridin, 2005; Suharto \& Budi Cahyono, 2005; Hakim, 2006; Devi, 2009; Gunastri, 2009; Haryono, 2009). Thus, the proposed hypothesis of the study as follows:

$\mathrm{H}_{2 \mathrm{a}}$ Work Motivation has a positive and significant effect on organizational commitment

$\mathrm{H}_{2 \mathrm{~b}}$ Work Motivation has a positive and significant effect on employee performance

\subsection{Organizational Culture}

Culture is the essence of what is important in the organization. As the activity of giving orders and prohibitions, and describe something done and not done that govern the behavior of members. So culture contains what we may do or not to do so can be considered as a guideline that is used to run the activities of the organization. Basically the organization within the company culture is a tool to unite every individual who perform activities together (Beach, 1993: 12). Organizational culture is often portrayed in the sense that is shared (Glaser et al., 1987).

Culture is the various interactions of traits habits that affect groups of people in the environment (Hofstede, 1986: 21). Organizational culture is a social adhesive that given the members of the organization. It seems to be a characteristic or personality varies from one person to another person can be incorporated into a strength of the organization it is necessary to social adhesive (Kreitner \& Kinicki, 1995: 532). The value of philosophy explained that the philosophy of the organization's founder developed and modern philosophy is always based on five values: integrity, identity, responsibility, and discipline and results orientation. That the values prevailing in the organization play an important role in instilling the culture of the organization to the members of the organization to have a high organizational commitment in improving employee performance. Empirical evidence suggests that organizational culture has positive and significant effect on organizational commitment and individual performance (Moon, 2000; Fey \& Denison, 2003; Abdul Rashid et al., 2003; Jandeska \& Kraimer, 2005; Cuong \& Swierczek, 2008; Manetje \& Martins, 2009; Zain et al., 2009; Ojo, 2009). Thus, the proposed hypothesis of the study as follows: 
$\mathrm{H}_{3 \mathrm{a}}$ Organizational culture has a positive and significant effect on organizational commitment

$\mathrm{H}_{3 \mathrm{~b}}$ Organizational culture has a positive and significant effect on employee performance

\subsection{Organizational commitment}

Organizational commitment is seen as a value orientation toward the organization that shows individuals highly thought of and prioritizing the work and organization. Individuals will try to give all its business in order to help the organization achieve its objectives. Organizational commitment is defined as the degree to the employee Identifies with a particular organization and its goals, and wishes to maintain membership in the organization (Robbins, 2003). Organizational commitment as the relative strength of the individual against an organization and its involvement in a particular organization, which is characterized by three psychological factors (Porter et al., 1973), namely: (1) A strong desire to remain a member of certain organizations, (2) The desire to bend over backwards for the sake of the organization and (3) Trust is definite and acceptance of the values and goals of the organization.

Three forms of organizational commitment (Allen \& Meyer, 1990), namely: (1) commitment Affective, that emotional attachment, identification and involvement in an organization. In this case the individual resides in an organization because of their own desires, (2) Commitment continuant, namely the commitment of individuals based on considerations about what must be sacrificed when it will leave the organization. In this case the individual decides to settle on an organization regarding it as a fulfillment of needs, (3) Normative commitment, namely the individual's beliefs about the responsibilities of the organization. Individuals remain in an organization because they feel obliged to loyal to the organization

Smith \& Meyer (2009: 56) states that everyone in the organization must be committed to advance, comply with the rules, become part of the organization and strive to maintain the organization's success has been achieved, The core of this organization's commitment includes four elements, namely affective, normative, continuous and prospective as demands for realizing the objectives of the organization. The findings of previous researchers provide evidence that organizational commitment has a positive and significant effect on employee performance (Suliman, 2002; Suharto \& Budi Cahyono, 2005; Khan et al., 2010). Thus, the proposed hypothesis of the study as follows:

$\mathrm{H}_{4} \quad$ Organizational commitment has a positive and significant effect on employee performance

\subsection{Employee performance}

Individual will always crave appreciation of the results of his work, and expect a fair wage. Performance appraisal needs to be done as objectively as possible because it will motivate employees to conduct their activities. Beside that also performance appraisal can provide information for the benefit of salary, promotion and see the behavior of employees. Performance is a combination of behavior with the achievement of what is expected and the choice or part of the terms of an existing task on each individual in the organization (Waldman, 1994).

Individual performance is the result of the quality and quantity of work that can be achieved by an employee in carrying out their duties in accordance with the responsibilities given to him (Mangkunegara 2001: 67). Performance is employee performance of duties which have been assigned duties (Cascio, 1995: 275). Performance is the result of the work of an employee during period particular compared with a range of possibilities, such as standards, target, and criteria that have been determined in advance and have been agreed (Soeprihantono, 1988: 7). The performance evaluation is based on aspects of quantity, quality, and time and costs (the Indonesian Government Regulation No. 46, 2011). Performance is the achievement of the work which exceeded the target set. Thus, the proposed hypothesis of the study as follows:

$\mathrm{H}_{5 \mathrm{a}}$ Competence has a positive and significant effect on employee performance is mediated by organizational commitment

$\mathrm{H}_{5 \mathrm{~b}}$ Work motivation has a positive and significant effect on employee performance is mediated by organizational commitment

$\mathrm{H}_{5 \mathrm{c}}$ Organizational culture has a positive and significant effect on employee performance is mediated by organizational commitment

\section{METHODS}

Explanatory research is done to explain the symptoms caused. The study was conducted on fourteen Institutes for education and training scattered South Sulawesi province. The research was scheduled for four months starting in December, 2015 until March, 2016. The population in this study of 513 employees working at fourteen Institute for education and training of South Sulawesi province. Sampling studies using formulations 
Slovin, thereby obtained 224 respondents. Analysis of the data used in explaining the phenomenon in this study is a descriptive statistical analysis techniques and analysis of Structural Equation Modeling (SEM).

\section{RESULTS}

The model is said to be good if the development hypothetical model theoretically supported by empirical data. Results of testing the goodness of fit indices in the following table with the criteria presented models as well as critical values that have compatibility data.

Table 2. Goodness of fit indices

\begin{tabular}{|l|c|c|c|}
\hline \multicolumn{1}{|c|}{ Goodness of fit } & Cut-off Value & Early & Final \\
\hline \multicolumn{1}{|c|}{ Chi-Square } & expected that a small & 279,287 & 258,836 \\
\hline Probability & $\geq 0.05$ & 0,000 & 0,219 \\
\hline CMIN/DF & $\leq 2.00$ & 1,990 & 1,072 \\
\hline RMSEA & $\leq 0.08$ & 0,067 & 0,018 \\
\hline GFI & $\geq 0.90$ & 0,839 & 0,921 \\
\hline AGFI & $\geq 0.90$ & 0,800 & 0,893 \\
\hline TLI & $\geq 0.94$ & 0,568 & 0,969 \\
\hline CFI & $\geq 0.94$ & 0,621 & 0,975 \\
\hline
\end{tabular}

Source: Data processed (2016)

The results of the evaluation of the models show that all the criteria of goodness of fit indices have met the criterion or criteria appropriate cut-off value, so that the models can be said to have been in accordance with the criteria of goodness of fit indices for analysis. Based on the empirical models proposed in this study can be tested against the hypothesis put forward by testing the path coefficients in structural equation modeling. The following table is a hypothesis testing by viewing the p-value. The test results are presented in the following table:

Table 3. Hypothesis testing

\begin{tabular}{|c|c|c|c|c|}
\hline \multirow{2}{*}{ Exogenous } & \multirow{2}{*}{ Endogenous } & \multicolumn{3}{|c|}{ direct effects model } \\
\hline & & Standardize & P-Value & Description \\
\hline Competence $\left(\mathrm{X}_{1}\right)$ & Organizational commitment (Y) & 0.284 & 0.011 & Significant \\
\hline Work Motivation $\left(\mathrm{X}_{2}\right)$ & Organizational commitment (Y) & $-0,013$ & 0,885 & insignificant \\
\hline Organizational Culture $\left(\mathrm{X}_{3}\right)$ & Organizational commitment (Y) & 0,375 & 0,003 & Significant \\
\hline Competence $\left(\mathrm{X}_{1}\right)$ & Employees performance $(\mathrm{Z})$ & 0.351 & 0.018 & Significant \\
\hline Work Motivation $\left(\mathrm{X}_{2}\right)$ & Employees performance $(\mathrm{Z})$ & -0.005 & 0.957 & insignificant \\
\hline Organizational Culture $\left(\mathrm{X}_{3}\right)$ & Employees performance $(\mathrm{Z})$ & 0.277 & 0.049 & Significant \\
\hline Organizational Commitment (Y) & Employees performance $(\mathrm{Z})$ & 0.426 & 0.005 & Significant \\
\hline Exogenous & Intervening & Endogenous & Standardize & Description \\
\hline Competence $\left(\mathrm{X}_{1}\right)$ & Organizational commitment $(\mathrm{Y})$ & Employees performance (Z) & 0.121 & Significant \\
\hline Work Motivation $\left(\mathrm{X}_{2}\right)$ & Organizational commitment $(\mathrm{Y})$ & Employees performance $(\mathrm{Z})$ & -0.006 & insignificant \\
\hline Organizational Culture $\left(\mathrm{X}_{3}\right)$ & Organizational commitment $(\mathrm{Y})$ & Employees performance (Z) & 0.160 & Significant \\
\hline
\end{tabular}

Source: Data processed (2016)

The overall model can be seen there are five direct effect path coefficient testing show positive and significant results, while the other two lines coefficient showing negative and insignificant results. Further testing indirect effect path coefficients showed that there are two indirect effect path coefficient tests which showed a positive and significant, while one of them showed a negative and insignificant. For it can be explained that the findings of this study, as follows: (1) competence has a positive and significant effect on organizational commitment, It can be proved by the standardized regression weight estimate of 0,284 and the probability value of $0.011<0,05$; (2) work motivation has a negative and insignificant effect on organizational commitment, It can be proved by the standardized regression weight estimate of $-0,013$ and the probability value of $0.885>0,05$; (3) organizational culture has a positive and significant effect on organizational commitment, It can be proved by the standardized regression weight estimate of 0,375 and the probability value of $0.003<0,05$; (4) competence has a positive and significant effect on employee performance, It can be proved by the standardized regression weight estimate of 0,351 and the probability value of $0.018<0,05$; (5) work 
motivation has a negative and insignificant effect on employee performance, It can be proved by the standardized regression weight estimate of $-0,005$ and the probability value of $0.957>0,05$; (6) organizational culture has a positive and significant effect on employee performance, It can be proved by the standardized regression weight estimate of 0,277 and the probability value of $0.049<0,05$; (7) organizational commitment has a positive and significant effect on employee performance, It can be proved by the standardized regression weight estimate of 0,426 and the probability value of $0.005<0,05$.

Further explanation for the indirect effect as follows: (1) Competence has a positive and significant effect on employee performance is mediated by organizational commitment, the standardized regression weight estimate of 0,121 and the value of the probability of $0.018<0,05$; (2) Work motivation has a negative and insignificant effect on employee performance is mediated by organizational commitment, the standardized regression weight estimate of 0,006 and the value of the probability of $0.957<0,05$; (3) organizational culture has a positive and significant effect on employee performance is mediated by organizational commitment, the standardized regression weight estimate of 0,160 and the value of the probability of $0.049<0,05$.

\section{CONCLUSION AND RECOMMENDATIONS}

Knowledge, skills, experience, attitude and skill mastery owned employees give a real effect in increasing organizational commitment and employee's performance. Integrity, responsibility, discipline and orientation results indicated employee apparently was able to increase the commitment of employees, on the other hand urge the fulfillment of necessities of life, physical, family, social becomes a factor that causes low levels of employee commitment and performance of employees. Organizational culture has been well used and understood thus providing a real impact against the organizational commitment and employee's performance. Organizational commitment as a mediating variable in explaining the effect of work motivation on employees performance, whereas in, explains the effect of competency and organizational culture on performance, organizational commitment is not proven. It takes strong efforts from the management to improve the employees work motivation through improvements on the necessities of life, physical, social and family.

\section{REFERENCES}

[1]. The Institute for Education and training of South Sulawesi Province (2016). Employee Activities. Makassar

[2]. Philips, Djordy. (2009). The Human resource Organization. Greenwich, CT : JAI Press.

[3]. Smith, Charvert and Meyer, G. (2009). The Good Perspective Theory for Commitment Organization. Prentice Hall, Ohio University Press.

[4]. Bani-Hani, J. S., \& AlHawary, F. (2009). The impact of core competencies on competitive advantage: Strategic challenge. International Bulletin of Business Administration, 6(6), 93-104.

[5]. Kanfer, R., Wolf, M. B., Kantrowitz, T. M., \& Ackerman, P. L. (2010). Ability and trait complex predictors of academic and job performance: A person-situation approach. Applied Psychology, 59(1), 40-69.

[6]. Rosa, D. M. (2011). Influence of soft competency of employees on performance of employees (study on employees of PT Taspen Malang). Influence of soft competency of employees on employees performance (study on PT Taspen Malang)

[7]. Sujana, E. (2012). The Influence of the Competence, Motivation, suitability for the role of organizational commitment on The internal Auditor's Performance (Study In Inspectorate Office Badung And Buleleng). JINAH (scientific journal accounting and Humanika), 2 (1).

[8]. Donald, Mc.Eachern, Thomas, (2007). Competence of Personal in Prospective Theories. http://www.journal human resource management.com.id.

[9]. Hersey, Paul \& Blanchard, Kenneth H, (2012). Management Organizational Behavior, Utilizing Human Resources. ${ }^{\text {th }}$. Ed. Englewood Cliffs, New Jersey, Prentice-Hall, Inc.

[10]. Moon, M. J. (2000). Organizational commitment revisited in new public management: Motivation, organizational culture, sector, and managerial level. Public Performance \& Management Review, 177-194.

[11]. Burton, J. P., Lee, T. W., \& Holtom, B. C. (2002). The influence of motivation to attend, ability to attend, and organizational commitment on different types of absence behaviors. Journal of Managerial Issues, 181-197.

[12]. Guritno, Bambang \& Waridin. (2005). The influence of Employee Perceptions Regarding Leadership Behavior, job satisfaction and motivation on performance. JRBI, vol. 1 No. 1, pp. 63-74

[13]. Suharto \& Budi Cahyono (2005), Organizational culture, leadership and work motivation on the performance of human resources in the secretariat DPRD for the Central Java Provincial , JRBI Vol. 1, No. 1, Januari 2005 : 13-30

[14]. Hakim, Abdul. (2006). The influence of motivation, organizational commitment and Organizational Climate on employee performance at the Department of transportation and telecommunications of Central Java 
[15]. Devi, E. K. D. (2009). Analysis Of The Influence Of Job Satisfaction And Motivation On Performance Of Employees With Organizational Commitment As An Intervening Variable. (Study on The outsourcing employees of PT Buana Semarang) (Doctoral dissertation, Diponegoro University Graduate Program).

[16]. Gunastri, Ni Made (2009). The effect of Individual Characteristics, Job Characteristics, Characteristics on the Organizational Performance and Work Motivation (Study on CV Kecak Denpasar) Jurnal Forum Manajemen, Vol. 7.

[17]. Haryono (2009). The effect of Work Characteristics and Compensation on employee performance as an mediation of work motivation (Study on the implementing agency for agricultural extension Officers, fisheries and forestry in Batang). Unpublished Thesis, Graduate School of Management Master's Degree Stikubank University, Semarang

[18]. Fey, C. F., \& Denison, D. R. (2003). Organizational culture and effectiveness: can American theory be applied in Russia?. Organization science, 14(6), 686-706.

[19]. Abdul Rashid, Z., Sambasivan, M., \& Johari, J. (2003). The influence of corporate culture and organisational commitment on performance. Journal of management development, 22(8), 708-728.

[20]. Jandeska, K. E., \& Kraimer, M. L. (2005). Women's perceptions of organizational culture, work attitudes, and role-modeling behaviors. Journal of managerial Issues, 461-478.

[21]. Cuong, D. M., \& Swierczek, F. W. (2008). Corporate culture, leadership competencies, job satisfaction, job commitment, and job performance: A comparison of companies in Vietnam and Thailand. Journal of American academy of business, 13(1), 159-165.

[22]. Manetje, O. dan N. Martins, 2009, The Relationship between Organizational Culture and Organizational Commitment, Southern African Business Review, 13(1): 87-111.

[23]. Zain, Z. M., Ishak, R., \& Ghani, E. K. (2009). The influence of corporate culture on organisational commitment: A study on a Malaysian listed company. European Journal of Economics, Finance and Administrative Sciences, 17(17), 16-26.

[24]. Ojo, O. (2009). Impact assessment of corporate culture on employee job performance. Business Intelligence Journal, 2(2), 388397.

[25]. Ruky, A. (2006). Human Resources-Quality Change The Vision Into Reality. The Second Edition. Jakarta: PT. Gramedia Pustaka Utama

[26]. Rivai, Veithzal. (2008). Performance Appraisal. Eagle Press, Jakarta

[27]. Thierauf, Frederick. (2008). Perspective The Competency HRM. Harper and Row, New York.

[28]. Heidjrachman \& Suad Husnan, (2000). Personnel Management, 4th Edition, the ninth Prints, BPFE, Yogyakarta.

[29]. Nawawi Hadari. (2000). Personnel administration for increased work productivity. Jakarta.Haji Intermedia

[30]. Beach Lee Roy. (1993). Making The Right Decision Organiztional Culture, Vision and Planning. United States of America: Prentice-Hall Inc.

[31]. Glaser, Susan R, Zamanou, Sonia \&Kenneth Hacker, (1987). Measuring and Interpreting Organizational Culture. Management Communication Quartely Vol.1 No.2 pp 173-178.

[32]. Hofstede, Geert, (1986). Culture's Consequences, International Differences in Work - Related Values. Sage Publication, Beverly Hills/London/New Delhi.

[33]. Kreitner, R., \& Kinicki, A. (1995) Organizational Behavior, Chicago: R.D. Irwin Inc.

[34]. Robbins, P. Stephen, (2003). Organizational Behavior: Concepts, Controversies, and applications. Interpreting Handayana Pujaatmika. Indonesian Language Edition. Jakarta: Prenhalindo

[35]. Porter, Lyman W., \& Steers RM. (1973). Organizational, Work, and Personal Factors in Employee Turn Over and Absenteeism. Psychological Bulletin. 80 (2): 151-176.

[36]. Allen, NJ, \& Meyer JP. (1990). The Measurement and Antecendents of Affective, Continuance and Normative Commitment to the Organization, Journal of Occupational Psychology. Vol.63. Number 1. pp. 1-18.

[37]. Suliman, A. M. (2002). Is it really a mediating construct? The mediating role of organizational commitment in work climateperformance relationship. Journal of Management Development, 21(3), 170-183.

[38]. Khan, M. R., Ziauddin, J. F., \& Ramay, M. I. (2010). The impacts of organizational commitment on employee job performance. European Journal of Social Sciences, 15(3), 292-298.

[39]. Waldman, D. A. (1994). Designing Performance Management Systems for Total Quality Implementation. Journal of Organizational Change Management, 7(2), 510-536

[40]. Mangkunegara, Anwar Prabu. (2001), Human resources management, Bandung : Remaja Rosdakarya

[41]. Cascio, Wayne F, (1995),Managing Human Resources: Productivity, Quality of worklife, Profits. Fourth Edition. Singapore : McGraw Hill Inc.

[42]. Soeprihantono, J., (1988), Assessment of the implementation of the employment and employee development. Yogyakarta : BPFE-Yogyakarta 